LETTERS TO TIIE EDITOR

[ The Editor does not hold himself responsible for opinions expressed by his correspondents. Neither can he undertake to return, or to correspond with the zuriters of, rejected manuscripts. No notice is taken of anonymous communications.

[The Editor urgently requests correspondents to keep their letters as short as possible. The pressure on his space is so great that it is impossible otherwise to insure the appearance even of communications containing interesting and novel facts.]

\section{The Relative Efficiency of War Ships}

I HAVE a complaint to make against certain of the statements made in the article upon "The Relative Efficiency of War Ships," which appe ared in your number for February 26 . It is incorrect to declare that I advocated before the Committee on Naval Designs, in $187 \mathrm{r}$, the system of construction upon which the ships of the Adm iral class are built. The Ajax, Agamennon, Colosists, and Edinlurgh are designet upon a citadel system which I originally devised and advocated under certain limitations; but I deny, and always have denied, that any of those ships conformed to the fundamental and indispensable condition which I laid down as part of my systen : viz. that the armoured citadel should be of ample dimensions to command the whole structure, lkeeping it afloat and upright, notwithstanding any amount of injury to the unarmoured ends. As this system has beer violated in all the four ships above-mentioned, it is most unfair and improper to state that even those vessels are constructed upon an system which I advocated. But as regards the ships of the Admiral class they do not at all conform to the system which I advised, and the writer of the article in question could only have supposed them to do so from a serious misapprehension of the ships themselves. The article stated that the central part of all the ships in question, including the Admiral class, are "plated completely around with very thick armour, which extends from the upper deck to scvcral fect below the water-line." This is a very incorrect description of the Admiral class, the armour in which does not rise to the upper deck at all, but is stopped in the form of a shallow belt rising but a foot or two, or possibly slightly more, above the water's surfacc. I repudiate with indignation the statement that such a system of construction as this, in association with the long unarmoured ends of the Admiral class, was ever recommended by me. For this reason I complain likewise of the statement in your article to the effect that my recent letter to the Times is but a continuation of the old and well-remembered Inflexible debate. So far is this from being so, that I distinctly pointed out in that letter that the cutting down of the armour to a mere belt of short length separated the ships of the Adrniral class from the others, and imported "a new ancl terrible causc of danger." Another statement of which I complain, and which I desire to lave currected, is to the effect that I "refised to give evidence" before the Infiexible Committee. Were this true, it would constitute, in my judgment, a most serious ground of complaint against me, but it is not true. The Inflexible Report and its Appendices clearly exhibit the fact that within two days of the appointment of the Committee, and on the very day on which my evidence was asked for by the Com. mittec, I hamed in to that borly a mosi claborate mass of evidence, occupying no less than eighteen columus of the In flewihle Report, and illistrated by two sheets of drawings, this evidence setting forth in great detail my views of the subject, and the grounds of my dissatislaction with such ships. It is true that four months later I was asked by telegram to attend the Conmittee, but asked to be excised on the ground that $I$ objected to take part in the dilatory procedings of the Committee, which I regarded as frustrating the oijects with which it was demanded by Parliament. My full evidence was, however, alreaty before the Commitlee, and had been for scveral months.
The above are the points of which I complain, and wish to have corrected. I do not ask as a matter of right, but I desire to have stated, that the long explanation which was given in the article in question for the purpose of showing that mere displacement is not, under all circumstances, a nueasure of the power of a ship, was, in my opinion, wholly unnecessary - at any rate, in so far as either Mr. Barnaby or myself was concerued. Both Mr. Barnaby and myself knew perfeclly well that clisplaccment is but a very rought measure of the power of ships, and no measure at all when ships of wholly different classes, and kinds, and dates, and systems are closely compared together. The only use that I made of the principle in my letter was to accept it for the moment as a rough basis of comparison betwecn the ten latest French and the len latest English ships, and I consider that for that purpose it was a gool enough principle to indicate the inferiority of the English ships. But the acceptance of the principle for that purpose in no way preclucled me from going further and showing that this rough comparison did not by any means bring to light other elements of grave inferiority, and even of danger, in the English vessels.

In the accompanying diagram the great difference between the Inflexible or Agamemnon class and the ships of the Admiral class is clearly illustrated. In both figures that part of the armour which is above the water is shown in full black, the part bclow the water being indicated by dotted lines. A glance at the diagram is sufficient to make it readily understood that the

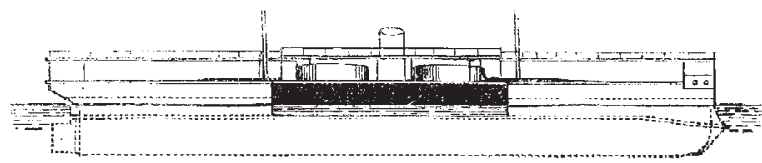

Agamemnon

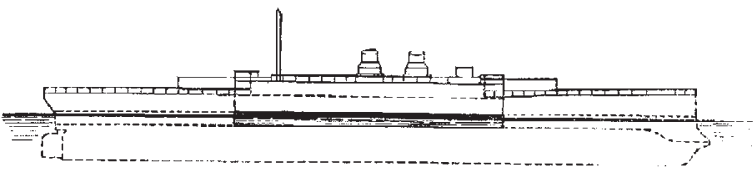

Collingrood

Agamemnon, whose sile armour rises several feet above the water, can be inclined to a considerable angle before her armour is brought under the water, whereas a very slight inclination only is nccessary to bring the extremely shallow armour of the Collingwood under the water. In the case of the Agamemnon, therefore, the armour she possesses affords her a considerable amount of resistance to capsizing, while the resistance thereto derived by the Collingrood from her armour is almost nil. The same remark applies, of course, to the buoyancy of the armoured out-of-water parts of the two ships, the Collingurood having but a small fractional part of that which the Agamemnon possesses.

\section{F. J, REes}

[We give inscrtion to this communication from Sir Lilwarr keed with great pleasure, because one of the chicf objects wc sought in our article was to support his view that the stability of the ships of the Atmiral class under the conditions which might be expected to vecur in a naval engagement was open to grave question, and to reassert that further scientific experiments should be made.

Wo regret that the fundamental difference, so far as fighting stability is concerned, letween ships of the Inflexible and Admiral type, which is now hrought out so well by Sir E. J. Reted's diagrams, was not emphasized in the article so strongly as it should have been, -F.n.] 